\title{
Correspondence
}

\author{
G. William Skinner's review of Urban Networks in Ch'ing China and Tokugawa \\ Japan
}

This review signals the beginning of a long-anticipated debate over alternative approaches to the study of premodern Chinese cities and other central places. As the pioneer who raised this field to a high level of social science rigor, Professor Skinner merits considerable recognition; any effort by him to maintain or upgrade standards for scholarship must command serious attention. Moreover, his decision to differentiate sharply, even if only by implication, my approach from his own can serve the positive function of heightening awareness of alternatives. Controversy, however, can assume either of two forms. In this case, he has chosen simply to dismiss the essence of my approach rather than to present or refer to a foundation on which an informed decision among alternatives, hopefully leading to the superseding of existing approaches, can be made. Although I would welcome the opportunity, if space permitted, to reply specifically to various points in the review, I regard as the first priority the goal of launching the debate on a different plane by responding to three general issues. At the moment, such unresolved issues as the necessity of choosing intervals of a particular regularity and of romanizing place names in a certain manner could arouse spirited discussion without producing quick theoretical payoff.

The first issue that Professor Skinnner correctly identifies as crucial is the classification of central places into levels. How should information on the population scale, economic functions and administrative status of central places be incorporated into one or more systems of classification? Numerous possibilities exist, but each has its draw. backs. Separating out purely administrative levels complicates the task of comparing countries with varied criteria for designating political centers. Defining levels strictly by population impairs assessment of long-run change, due to the scarcity of data over time. My approach is not the shifty, inconsistent manipulation of levels that is indicated in the review. Rather I have distinguished two systems of defining levels. The two are not used interchangeably and I believe are not manipulated in an ad hoc manner. Their application provides a sound foundation for comparing the emergence of settlement types over time and for comparing the distribution of places of varying size. I know of no superior system of classification for either purpose. With the appearance of my book, Urban Networks in Russia, 1750-1800, and Premodern Periodization (Princeton: Princeton University Press, forthcoming), the reader will learn how essentially the same classifications facilitate fivecountry comparisons in which the Russian, English, and French cases have been added.

Second, Professor Skinner focuses on the issue of regionalization. I take it that there are two issues here: I) The superiority of physiographic units for analytical purposes; 2) the correct boundaries of those. In labeling my treatment of China wrongheaded, he merely declares that the only useful way of dividing the country is into physiographic regions, the evidence for which has yet to be published. Moreover, he claims as his own the finding that the high urbanization rate of Chihli must be seen against the context of the low urbanization rate of North China, a point I felt I had established by treating North China as a region (pp. 204-13), albeit not a region defined according to Professor 
Skinner's physiographic criteria. Again, he distorts my treatment of Japan, claiming as his own analysis the division of the country into eastern and western portions, although that is precisely the way I presented it in the book (pp. 252, 259, and 260). My focus on hinterlands of cities at various levels clearly indicates a concern for finding integrative zones independent of administrative boundaries (e.g., on pp. 299-300); I readily concede that the six regions I used represent only rough approximations of the largest integrative zones of cities at levels I and 2. With the publication of Professor Skinner's alternative system of regionalization we shall want to reexamine proposed boundaries, and I anticipate that the eventual debate over regions in Chinese history, however defined, will have far-reaching implications. He may well persuade me that his system is preferable, but in the absence of it 1 see no reason for holding research in abeyance.

Finally, I must respond briefly to criticisms of the abysmal scholarly paraphernalia, of ignoring literature on central place systems, and of the book's "lack of theory" by asking three questions: In what respects is the scholarly apparatus, including simple maps, insufficient or inappropriate for the purpose at hand? Does the current state of central place studies on premodern countries warrant drawing heavily on that literature for a book on China and Japan? Does my comparative book, explicitly designed for the development of theory, deserve such disparagement of its contributions toward that development? In ignoring the relevance of my approach for comparisons of societies, Professor Skinner has directed attention away from its major theoretical significance. Of course, the expansion to five-country comparisons provides a better foundation for generalizations, but I believe that I have set forth the basic theoretical issues in this volume, especially in the introductions and summaries and in the series of questions raised on p. 278. Genuine differences of approach apparently will exist in this field, and perhaps that can be fruitful; those ought not be obscured by intolerance usually reserved for a field of study in which a much higher degree of consensus has been achieved, particularly when no evidence for their invalidity has been offered or alluded to.

\section{GILBERT ROZMAN}

\section{Princeton University}

\section{Stephen Uballey Jr. and Westerners in China: a Furtber Comment}

Although it is not very becoming for scholars to seek to draw attention to their own work when commenting on the works of others, I hope I may be excused for doing so, since that pattern has been strongly set in this particular controversy by Stephen Uhalley's review of Jen Yu-wen's The Taiping Revolutionary Movement (JAS, August 1974), and his reply to Martin Ring's strictures on that review (JAS., May 1975).

Neither of the protagonists in this somewhat quixotic encounter appear to have surveyed the field very carefully before tilting their lances. Having written on both subjects, I find it surprising that they should, in 1975 , be arguing as if no one else has said anything very worthwhile about the Taiping occupation of Ningpo or the transfer of T. T. Meadows from Shanghai to Newchwang. Stephen Uhalley several times enjoins us to look at his article "The Taipings at Ningpo: the Significance of a Forgotten Event." I drew attention to the significance of this event in the history of Western, more specifically British, relations with the Taipings briefly in an article published in JAS in November 1959 (p. 15) and at more length in my Great Britain and the Taipings 
(Routledge and Praeger, 1969, pp. 102-3, 106-8, and 122-3). Whatever the value of his article, one thing that does seem to have been forgotten by Uhalley is the desirability of doing one's homework thoroughly before publishing under titles like that.

Both Uhalley and Ring might also have looked up my brief article "The Transfer of T. T. Meadows from Shanghai to Newchwang in 186I" (Historical Studies: Australia and New Zealand, Oct I966, pp. 435-9; duly listed in the bibliography of Great Britain and the Taipings), in which I set out to show that there was a great deal more involved in that transfer than simply removing a pro-Taiping consul from a key point of Western contact with the rebellion. That was part of it, certainly, but by no means the whole or perhaps even the greater part. Meadows' appointment at Shanghai was never more than temporary; he had requested a North China appointment for health and other reasons as soon as the Treaty of Tientsin made that a possibility in 1858; he was gazetted to Newchwang in 1859 , and in 1861 was happy to go there. Bruce was also happy enough to get him out of Shanghai, but as much because of his maverick attitude to the IMCS as for anything else; and Meadows was not in fact transferred before his gazetted appointment was actually available. It seems to me that Meadows was treated quite fairly by his superiors on this matter; and although he was resentful that more attention had not been paid to his views on policy toward the Taipings, he went to Newchwang more in hope and enthusiasm than resentment.

My study of Meadows' career over his whole period in China makes me doubt the accuracy of Rich's reference to his "roaring life style," in Shanghai or elsewhere. He was often cranky and cantankerous to a point that made others roar, but it was the crankiness of a scholar-a "pedant" as his superiors put it-rather than of a wild liver. I think Uhalley exaggerates the authority of Meadows' assessment of the rebel movement. He was anti-Manchu before he ever saw the Taipings; and he had direct contact with them for less than a week in 1853 and not again thereafter. By the early 1860 s there were many other Westerners, not all of them less reasonable men than Meadows, who had spent longer periods of time among the rebels and had observed them carefully, often sympathetically. But apart from an adventurer like Lindley or a rare, detached observer like R. J. Forrest, by 1862 they had nearly all written off the Taipings as without constructive potential. Meadows, characteristically, never shifted from the first view he took of them-a view, in my judgment, formed to some extent before he ever got to Nanking. For Uhalley to present him as a model of reasonableness and detachment is really far too simple; his whole career illustrates his proneness to rigidity and dogged unreasonableness - like many brilliant and original men.

The man was very complex, and so were the issues involved in assessing the rebellion and determining policy toward it. I have tried to make some contribution to understanding these complexities. That other scholars should produce more evidence and dispute my interpretations is to be expected, for that will o' wisp truth will only be glimpsed through an ongoing process of conjecture, argument, modification, and refutation. To be ignored, however, while others speculate and assert over ground one has already surveyed, is less acceptable. Effective scholarship demands communication; and that includes reading the writings of one's colleagues in the field, and considering their arguments even if they disagree with them.

J. S. GREGORY

La Trobe University

Melbourne, Australia 